\title{
Epidemiological characteristics and temporal trends of new leprosy cases in Brazil: 2006 to 2017
}

\author{
Características epidemiológicas e tendências \\ temporais de casos novos de hanseníase \\ no Brasil: 2006 a 2017
}

\section{Características epidemiológicas y tendencias temporales de nuevos casos de lepra en Brasil: de 2006 a 2017}

Júlia Moreira Pescarini 1,2

Camila Silveira Silva Teixeira 1,3

Nívea Bispo da Silva 1,4

Mauro Niskier Sanchez 1,5

Marcio Santos da Natividade 3

Laura Cunha Rodrigues 2

Maria Lúcia Fernandes Penna 6

Maurício Lima Barreto 1

Elizabeth B. Brickley ${ }^{2}$

Gerson Oliveira Penna 5,7

Joilda Silva Nery ${ }^{3}$

doi: 10.1590/0102-311X00130020

\begin{abstract}
Our study aims to describe trends in new case detection rate (NCDR) of leprosy in Brazil from 2006 to 2017 overall and in subgroups, and to analyze the evolution of clinical and treatment characteristics of patients, with emphasis on cases diagnosed with grade 2 physical disabilities. We conducted a descriptive study to analyze new cases of leprosy registered in the Brazilian Information System for Notificable Diseases (SINAN), from 2006-2017. We calculated the leprosy NCDR per 100,000 inhabitants (overall and for individuals aged $<15$ and $\geq 15$ years) by sex, age, race/ethnicity, urban/rural areas, and Brazilian regions, and estimated the trends using the Mann-Kendall nonparametric test. We analyzed the distributions of cases according to relevant clinical characteristics over time. In Brazil, there was a sharp decrease in the overall NCDR from 23.4/100,000 in 2006 to 10.3/100,000 in 2017; among children < 15 years, from 6.94 to 3.20/100,000. The decline was consistent in all Brazilian regions and race/ethnicity categories. By 2017, 70.2\% of the cases were multibacillary, 30.5\% had grade $1(G 1 D)$ or $2(G 2 D)$ physical disabilities at diagnosis and $42.8 \%$ were not evaluated at treatment completion/discharge; cases with G2D at diagnosis were mostly detected in urban areas (80\%) and 5\% of cases died during the treatment (leprosy or other causes). Although the frequency of leprosy NCDR decreased in Brazil from 2006 to 2017 across all evaluated population groups, the large number of cases with multibacillary leprosy, physical disabilities or without adequate evaluation, and among children suggest the need to reinforce timely diagnosis and treatment to control leprosy in Brazil.
\end{abstract}

Leprosy; Social Conditions; Neglected Diseases; Epidemiology; Time Series Studies

\author{
Correspondence \\ J. M. Pescarini \\ Centro de Integração de Dados e Conhecimentos para Saúde, \\ Fundação Oswaldo Cruz. \\ Rua Mundo s/n, Parque Tecnológico da Bahia, Salvador, BA \\ 41745-715, Brasil. \\ Julia.Pescarini1@lshtm.ac.uk \\ 1 Centro de Integração de Dados e Conhecimentos para Saúde, \\ Fundação Oswaldo Cruz, Salvador, Brasil. \\ 2 Department of Infectious Disease Epidemiology, London \\ School of Hygiene es Tropical Medicine, London, U.K. \\ 3 Instituto de Saúde Coletiva, Universidade Federal da Bahia, \\ Salvador, Brasil. \\ 4 Departamento de Estatística, Universidade Federal da Bahia, \\ Salvador, Brasil. \\ 5 Núcleo de Medicina Tropical, Universidade de Brasília, \\ Brasília, Brasil. \\ 6 Departamento de Epidemiologia e Bioestatística, Universidade \\ Federal Fluminense, Niterói, Brasil. \\ 7 Gerência Regional de Brasília, Fundação Oswaldo Cruz, \\ Brasília, Brasil.
}




\section{Introduction}

Leprosy is a chronic infectious disease caused by Mycobacterium leprae. In the absence of early diagnosis and adequate treatment, infections may lead to serious neurological impairment and potentially irreversible complications, including sensory loss, amyotrophy, deformities, and wounds on the hands and feet. Leprosy-associated disabilities can lead to social stigma, discrimination and deterioration of mental health, which may contribute to job loss and the perpetuation of the cycle of poverty 1.

In 2017, approximately $13 \%$ of the more than 200,000 cases of leprosy occurring globally were recorded in Brazil 2. Although the Brazilian leprosy control program data shows marked reduction in the frequency of leprosy in the general population in recent years, the distribution of leprosy is highly heterogeneous across Brazil 3. Clusters of leprosy cases, which are greatly significant for the public health, have been detected in the North, Central West, and Northeast regions 3,4 . Several capitals in the North and Northeast regions of the country have reported no reductions in leprosy cases in children aged under 15 years, suggesting there may be active transmission in these populations 5 .

Although social protection policies implemented in Brazil in the past decade have been associated with reduced incidence of leprosy in high-burden municipalities, recent austerity policies and increasing poverty rates in the country may have pushed leprosy incidence to higher levels and represented a set-back in Brazilian leprosy elimination targets 6,7. To understand the effect of these shifting pressures, this study aimed to describe the leprosy trends over time in the overall population and in subgroups and to analyze the distribution of clinical and treatment characteristics of patients diagnosed with leprosy in Brazil, with an emphasis on cases diagnosed with grade 2 physical disabilities (G2D). An improved understanding of the epidemiological profile of leprosy in Brazil and the cases diagnosed with advanced disease will help to quantify the burden of disease. In addition, this work will inform national strategies for prioritizing leprosy control interventions, including health promotion/education, contact surveillance/case finding, and disability treatment/rehabilitation.

\section{Methods}

\section{Design, data source and study population}

This is a descriptive study that analyzed new cases of leprosy reported in Brazil between 2006 and 2017. The analysis is based on: (i) de-identified leprosy records obtained from the Brazilian Information System for Notificable Diseases (SINAN-leprosy) (2006-2017); and (ii) demographic data from the population census of the Brazilian Institute of Geography and Statistics (IBGE) (2000 and 2010). The SINAN-leprosy data were obtained in March 2019 with the Citizens' Information Service Electronic System (e-SIC; https://esic.cgu.gov.br/falabr.html). This study dataset included records from all new cases of leprosy detected between January 1, 2006, and December 31, 2017.

\section{Variables and data analysis}

The data extracted from SINAN-leprosy included demographic and socioeconomic variables, i.e., age, sex, schooling, race/ethnicity, region of residence in Brazil and residential area (rural and urban); clinical variables, i.e., clinical form (indeterminate, tuberculoid, borderline and lepromatous); operational classification (paucibacillary or multibacillary), grade of physical disability at time of diagnosis and at the end of the treatment (grade $0-$ GOD, grade $1-$ G1D, and grade $2-$ G2D); presence of leprosy reaction during treatment (reaction 1,2, or 1+2); and treatment outcome (cure, transfer to other health units, municipalities or state, dropout, or death).

The population composition of Brazil was obtained from 2000 to 2017 overall and by state. From 2000 to 2017, yearly population distributions were available for age and sex, but were not available for the variables of race/ethnicity and residential area (rural or urban). Hence, for comparability between the four variables, i.e., age, sex, race/ethnicity and residential area, we used linear interpolation and extrapolation based on the 2000 and 2010 census data to calculate the population distributions for the years of 2006-2009 and 2011-2017. 
We conducted a descriptive analysis, including the absolute numbers and frequencies and/or means and standard deviations (SD) to investigate the distribution of sociodemographic characteristic of individuals who were newly diagnosed with leprosy in the study period (2006-2017). We estimated the annual new case detection rate (NCDR) of leprosy per 100,000 individuals across the full population of Brazil and by geographic (i.e., region of Brazil and residential area) and sociodemographic variables (i.e., sex, age, and race/ethnicity) from 2006 to 2017. We also calculated the male:female ratio of the number of new leprosy cases detected and estimated leprosy reductions from 2006 to 2017 NCDR as 1 - NCDR2017/NCDR2006 in order to verify changes over time. The leprosy NCDR trends by sociodemographic characteristics were evaluated using the Mann-Kendall non-parametric test, which tests if the time series has a monotonic tendency over time. Kendall's correlation coefficients were estimated to evaluate if the correlations between the series of detection rates versus time were positive or negative. Finally, we conducted a secondary descriptive analysis to investigate the distribution of sociodemographic and clinical characteristics of new leprosy cases diagnosed with G2D in 2006 and 2017.

All analyses were carried out using R Studio 5.4.1 (http://www.r-project.org) and Stata version 15 (https://www.stata.com).

\section{Ethical aspects}

Three Research Ethics Committees approved this study: (i) the University of Brasília (1.822.125), (ii) the Gonçalo Muniz Institute/Oswaldo Cruz Foundation (1.612.302), and (iii) the London School of Hygiene \& Tropical Medicine (10580-1).

\section{Results}

\section{Leprosy NCDR trends}

Between 2006 and 2017, a total of 396,989 new cases of leprosy were recorded in Brazil. Overall, the NCDR decreased from 23.4/100,000 in 2006 to 10.2/100,000 in 2017 (56.4\% reduction) (Table 1). Although reductions in NCDR occurred in all five country regions, the magnitude of these declines varied. Specifically, the highest reductions between 2006 and 2017 took place in the South $(70.9 \%$ reduction), Southeast (67.8\% reduction) and North regions (63.5\% reduction) (versus 50\% reductions in North and 49.9\% in the Central West) (Figure 1a). As of 2017, the Central West (NCDR2017: 25.7/100,000) and North regions (NCDR2017: 22.8/100,000) had the highest leprosy detection coefficients. Downward trends in the overall leprosy NCDR were observed in both the urban and rural areas (Figure 1b), among both men and women (Figure 1c) and across all ages (Figure 1d) and racial/ ethnic groups (Tables 1 and 2). Among children aged under 15 years, 25,688 new cases of leprosy were identified during the study period, equivalent to $6.5 \%$ of all the cases in the country. The NCDR among children was approximately halved from 6.9/100,000 in 2006 to 3.2/100,000 in 2017.

Despite the widespread decreases in leprosy NCDR from 2006 to 2017, it remained disproportionately higher in some groups - the NCDR among men was higher than that among women across all years evaluated, and the male:female ratio of 1:2 remained consistent over time (Table 1). Similarly, the highest NCDR was consistently observed among individuals aged 60 or older. Overall, the age at new case detection became higher over time, with the mean age increasing from 41.9 years $(S D=20.2)$ in 2006 to 46.3 years $(S D=19.8)$ in 2017. The highest NCDRs were also recorded in 2017 for individuals self-identified as Black (15.3/100,000), Indigenous (14.2/100,000) and Brown (13.1/100,000) (Table 1). Whereas one of the highest NCDRs were recorded among the indigenous population, the number of cases was much smaller than in other racial/ethnic groups. 
Table 1

Frequency and new case detection rate (NCDR) of leprosy per 100,000 population by sociodemographic characteristics and residential area in Brazil from 2006 to 2017 ( $N=396,989)$.

\begin{tabular}{|c|c|c|c|c|c|c|c|c|}
\hline \multirow[t]{2}{*}{ Variables } & \multicolumn{3}{|c|}{$2006-2017$} & \multicolumn{2}{|c|}{2006} & \multicolumn{2}{|c|}{2017} & \multirow[t]{2}{*}{ Reduction * (\%) } \\
\hline & $\mathbf{N}$ & $\%$ & Mean NCDR & $\mathbf{n}$ & NCDR & $\mathbf{n}$ & NCDR & \\
\hline Total & 396,989 & & 16.9 & 43,744 & 23.4 & 21,244 & 10.2 & 56.3 \\
\hline \multicolumn{9}{|l|}{ Region } \\
\hline North & 79,568 & 40.6 & 40.6 & 9,384 & 62.5 & 4,095 & 22.8 & 63.5 \\
\hline Northeast & 165,630 & 25.4 & 25.4 & 16,977 & 32.9 & 9,403 & 16.4 & 50.0 \\
\hline Southeast & 68,317 & 6.9 & 6.9 & 8,645 & 10.9 & 3,043 & 3.5 & 67.8 \\
\hline South & 15,677 & 4.6 & 4.6 & 1,950 & 7.1 & 617 & 21 & 70.9 \\
\hline Central West & 67,723 & 38.9 & 38.9 & 6,845 & 51.6 & 4,081 & 25.7 & 49.9 \\
\hline \multicolumn{9}{|l|}{ Sex } \\
\hline Female & 177,646 & 44.8 & 15.5 & 20,151 & 21.7 & 9,630 & 9.2 & 57.8 \\
\hline Male & 219,322 & 55.3 & & 23,621 & 26.4 & 11,614 & 11.6 & 56.1 \\
\hline Male:Female ratio & & & 13.8 & \multicolumn{2}{|c|}{1.17} & \multicolumn{2}{|c|}{1.21} & \\
\hline Age group (years) & & & 17.7 & & & & & \\
\hline$<15$ & 28,729 & 7.2 & & 3,311 & 6.9 & 1,371 & 3.2 & 53.9 \\
\hline 15- 59 & 285,176 & 71.8 & & 32,635 & 28.0 & 14,510 & 10.5 & 62.4 \\
\hline $60+$ & 83,084 & 20.9 & 4.9 & 7,828 & 43.1 & 5,363 & 21.6 & 49.9 \\
\hline Race/Ethnicity & & & 17.2 & & & & & \\
\hline White & 113,139 & 28.5 & 29.5 & 13,933 & 15.3 & 5,188 & 5.8 & 62.5 \\
\hline Brown/Mixed race & 50,938 & 12.8 & & 21,561 & 28.4 & 12,481 & 13.1 & 65.1 \\
\hline Black & 209,928 & 52.9 & 9.6 & 5,622 & 43.8 & 2,604 & 15.3 & 53.8 \\
\hline Asian & 4,394 & 1.1 & 26.1 & 624 & 39.8 & 210 & 6.9 & 82.7 \\
\hline Indigenous & 1,616 & 0.4 & 18.8 & 127 & 16.2 & 125 & 14.2 & 12.3 \\
\hline Missing & & & 14.9 & 1,907 & & 636 & & \\
\hline Residential area & 307,459 & 77.5 & 15.0 & & & & & 48.9 \\
\hline Urban & 60,870 & 15.3 & & 28,712 & 18.9 & 17,107 & 9.7 & 31.5 \\
\hline Rural & 177,646 & 44.8 & 14.3 & 5,553 & 18.1 & 3,514 & 12.4 & 57.8 \\
\hline Missing & & & & 9,509 & & 623 & & 56.1 \\
\hline
\end{tabular}

Source: Brazilian Health Informatics Department (DATASUS) - http://www2.datasus.gov.br/DATASUS/index.php?area=0901 (accessed on 03/May/2019) and http://tabnet.datasus.gov.br/cgi/deftohtm.exe?popsvs/cnv/popbr.def (acccessed on 24/May/2019).

* Reduction of leprosy NCDR estimated by 1 - NCDR2017/NCDR2006.

\section{Evolution of leprosy diagnosis over time}

Between 2006 and 2017, the proportion of leprosy cases detected with severe manifestations of the disease increased over time (Table 3). Specifically, the percentage of borderline leprosy cases increased from $31.6 \%$ to $47 \%$, which corresponded to reductions in the tuberculoid and indeterminate forms. In addition, multibacillary cases increased from $52.9 \%$ to $70.2 \%$ (Table 3). The proportion of cases without reaction episodes during treatment doubled (from 32.2\% to 66.4\%), and in 2017, the majority of cases were evaluated for reaction (40.4\% vs. $78.6 \%$ ). Also, in 2017 , there was a larger proportion of cases that transferred to treatment in other health units (5.9\% in 2006 vs. $11.4 \%$ in 2017).

Although there was an overall reduction in the number of new cases, the percentage of cases with G1D or G2D disabilities increased from 22.6\% in 2006 to 30.5\% in 2017 (Figure 2a, Table 3), resulting in a NCDR of G2D of 6.92/1,000,000 cases in 2017 (data not shown). Similar trends were observed for children (Figure 2b), with NCDR of G2D of 0.91/1,000,000 children in 2017.

Over time, G1D and G2D contributed to a substantial number of new cases at diagnosis and at the end of treatment (Figure 3, Table 3). In 2017, among the 5,032 cases evaluated with G1D at diagnosis, 


\section{Figure 1}

New case detection rate (NCDR) of leprosy per 100,000 population by region of residence, urban and rural regions, sex, and age groups in Brazil from 2006 to 2017.

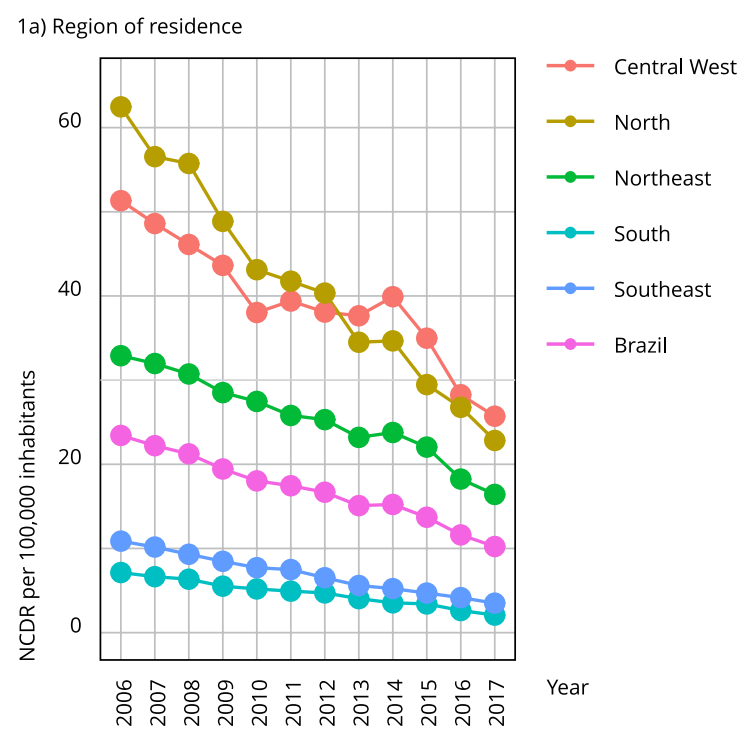

1c) Sex

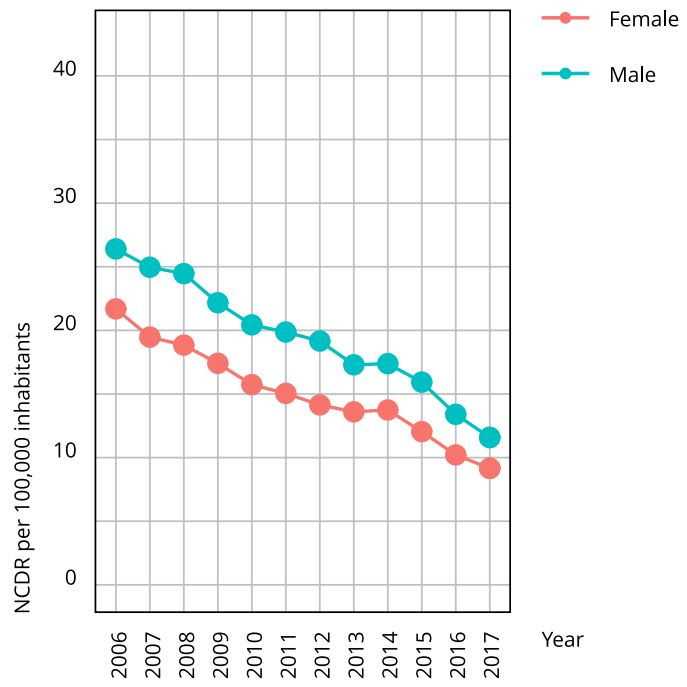

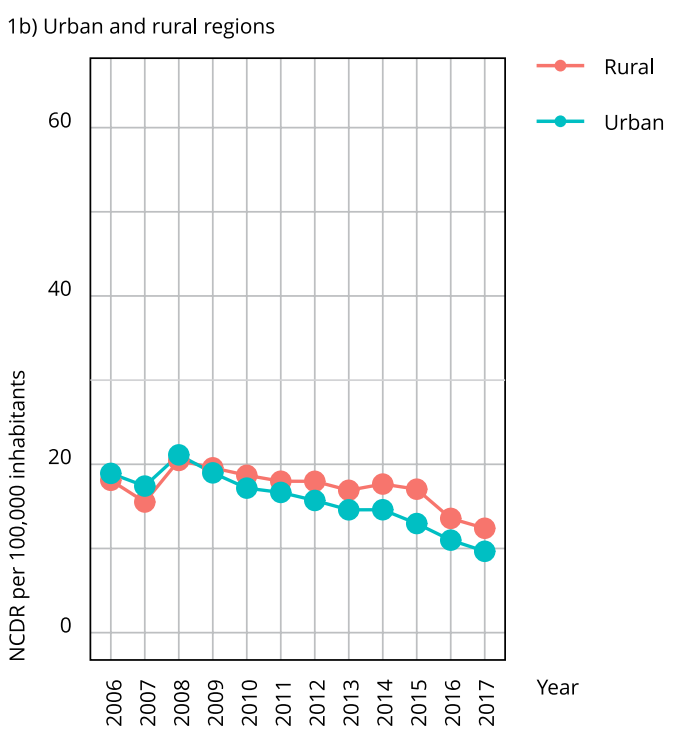

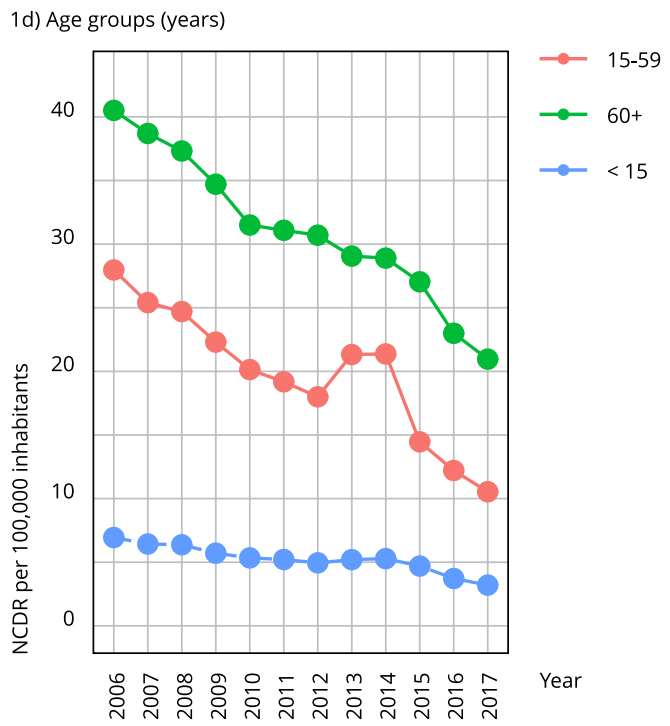

Note: for $1 b$, the rate differences in rates from national Brazilian data represents missing data.

1,459 (29\%) remained with G1D; 141 cases (2.8\%) progressed to more severe disability grades (G2D) and for 1,985 (39.4\%) there was no information on patients' disability grades at the end of treatment (Table 4, Figure 3). Among the cases diagnosed with G2D in 2017, 22.4\% of cases improved to G0D or G1D, but 35\% remained with G2D and for $42.7 \%$ the information on patients' disability grades at the end of treatment was not documented by a physician or health professional (Table 4, Figure 3 ). Overall, the disability grade at the end of treatment was not evaluated for $46.4 \%$ of cases in 2006 and 
Table 2

Time trends in the socioeconomic and demographic characteristics of new leprosy cases in Brazil from 2006 to 2017 evaluated using the Mann-Kendall test for monotonic trends and the Kendall rank correlation coefficient.

\begin{tabular}{|c|c|c|}
\hline Variables & Mann-Kendall statistic test & Kendall's $\tau$ \\
\hline \multicolumn{3}{|l|}{ Sex } \\
\hline \multicolumn{3}{|l|}{ Female } \\
\hline \multicolumn{3}{|l|}{ Male } \\
\hline \multicolumn{3}{|l|}{ Age group (years) } \\
\hline$<15$ & $-58.00 *$ & -0.88 \\
\hline $15-59$ & $-52.00 *$ & -0.79 \\
\hline $60+$ & $-66.00 *$ & -0.99 \\
\hline \multicolumn{3}{|l|}{ Race/Ethnicity } \\
\hline White & $-64.00 *$ & -0.97 \\
\hline Black & $-64.00 *$ & -0.97 \\
\hline Asian & $-66.00 *$ & -0.99 \\
\hline Brown/Mixed race & $-64.00 *$ & -0.97 \\
\hline Indigenous & -30.00 * & -0.45 \\
\hline \multicolumn{3}{|l|}{ Region } \\
\hline North & $-64.00 *$ & -0.97 \\
\hline Northeast & -64.00 * & -0.97 \\
\hline Southeast & $-66.00 *$ & -0.99 \\
\hline South & $-66.00 *$ & -0.99 \\
\hline Central West & $-54.00 *$ & -0.82 \\
\hline \multicolumn{3}{|l|}{ Residential area } \\
\hline Urban & -56.00 * & -0.85 \\
\hline Rural & $-40.00 *$ & -0.61 \\
\hline
\end{tabular}

* Evidence of trend effect.

42.8\% of cases in 2017 (Figure 3). A larger proportion transferred out to other health units (5.9\% in 2006 vs. $11.4 \%$ in 2017 ).

Among the subgroup of new cases with G2D, between 2006 and 2017 we observed increases in the percentages of individuals who were aged over 60 (32.4\% to 40.1\%), identified as Brown (44\% to $55 \%)$, resident in urban areas (60\% to $80 \%)$, and that were classified as multibacillary cases ( $88 \%$ to 95\%). Although the number of cases evaluated for reaction episodes during treatment decreased from $52.6 \%$ to $20.6 \%$ in 2017 , among those evaluated in $2017,29 \%(331 / 1,140)$ reported having some type of reaction episode. The proportion of G2D cases that were transferred out to continue treatment in other health units was 15\% in 2017 and almost 5\% have died during treatment as result of leprosy or from other causes (Table 5).

\section{Discussion}

This study described the epidemiological context for leprosy in Brazil and its regions in a historic series spanning twelve years. Between 2006 and 2017, despite overall reductions in the leprosy new case detection rates (reductions of over 50\%), Brazil continued to experience a high incidence of leprosy in the Central West, North, and Northeast regions, among men, individuals aged over 60 years, and individuals who identified as non-White (Black, Brown and Indigenous). There was an increased proportion of individuals newly diagnosed with multibacillary leprosy or diagnosed with leprosyassociated G1D or G2D, including a substantial number of children that continue to be detected with G2D. 
Table 3

Total number and percentage of new leprosy cases by clinical characteristics in Brazil from 2006 to 2017.

\begin{tabular}{|c|c|c|c|c|}
\hline \multirow[t]{2}{*}{ Clinical variables } & \multicolumn{2}{|c|}{2006} & \multicolumn{2}{|c|}{2017} \\
\hline & $\mathbf{n}$ & $\%$ & $\mathbf{n}$ & $\%$ \\
\hline Total & 43,774 & 100.0 & 21,244 & 100.0 \\
\hline \multicolumn{5}{|l|}{ Clinical form } \\
\hline Undeterminate & 8,986 & 20.5 & 3,141 & 14.8 \\
\hline Tuberculoid & 10,449 & 23.9 & 3,301 & 15.5 \\
\hline Borderline & 13,840 & 31.6 & 9,983 & 47.0 \\
\hline Lepromatous & 6,809 & 15.6 & 3,008 & 14.2 \\
\hline Not reported & 3,690 & 8.4 & 1,811 & 8.6 \\
\hline \multicolumn{5}{|l|}{ Operational classification } \\
\hline Paucibacillary & 20,526 & 46.9 & 6,328 & 29.8 \\
\hline Multibacillary & 23,145 & 52.9 & 14,916 & 70.2 \\
\hline Not reported & 103 & 0.2 & 0 & 0.0 \\
\hline \multicolumn{5}{|l|}{ Disability grade at diagnosis } \\
\hline Grade 0 & 29,811 & 68.1 & 12,375 & 58.3 \\
\hline Grade 1 & 7,495 & 17.1 & 5,032 & 23.7 \\
\hline Grade 2 & 2,416 & 5.5 & 1,436 & 6.8 \\
\hline Not reported & 4,052 & 9.3 & 2,401 & 11.3 \\
\hline \multicolumn{5}{|l|}{ Disability grade at end of treatment } \\
\hline Grade 0 & 18,486 & 42.2 & 9,112 & 42.9 \\
\hline Grade 1 & 3,728 & 8.5 & 2,253 & 10.6 \\
\hline Grade 2 & 1,240 & 2.8 & 784 & 3.7 \\
\hline Not reported & 20,320 & 46.4 & 9,095 & 42.8 \\
\hline \multicolumn{5}{|l|}{ Reaction episodes } \\
\hline No reaction & 14,116 & 32.2 & 14,097 & 66.4 \\
\hline Type 1 & 2,476 & 5.7 & 1,901 & 8.9 \\
\hline Type 2 & 751 & 1.7 & 485 & 2.3 \\
\hline Types 1 and 2 & 357 & 0.8 & 209 & 1.0 \\
\hline Not reported & 26,074 & 59.6 & 4,552 & 21.4 \\
\hline \multicolumn{5}{|l|}{ Treatment outcome } \\
\hline Cure & 38,209 & 87.3 & 17,223 & 81.1 \\
\hline Dropout & 2,339 & 5.3 & 1,211 & 5.7 \\
\hline Transferred health unit & 2,584 & 5.9 & 2,421 & 11.4 \\
\hline Death & 642 & 1.5 & 389 & 1.8 \\
\hline Average number of recorded contacts & 3.7 & 2.4 & 3.2 & 2.3 \\
\hline Average number of examined contacts & 2.1 & 2.3 & 2.8 & 2.2 \\
\hline
\end{tabular}

Our study provides evidence that leprosy remains endemic in Brazil as of 2017 (10.2/100,000), with strong heterogeneity and hyperendemic areas $(>20 / 100,000)$ in the North and Central West regions of the country. The Brazilian leprosy NCDR remains higher than across the World Health Organization (WHO) regions such as Americas $(2.86 / 100,000)$ or in other endemic regions, such as Southeast Asia $(7.72 / 100,000) 8,9,10$.

These data also indicate that Brazil continues to have a very high incidence of infection among children under 15 years of age 11 . This high burden in the pediatric population may reflect early infection of children and teenagers arising from sustained disease transmission associated with low detection rates and lack of timely treatment in adults with multibacillary leprosy 12,13. Studies carried out previously in Brazil, Saudi Arabia, Mexico, and South Korea provide evidence of a decreasing trend in the number of new leprosy cases among those under 15 years, which has been mainly attributed to the 
Figure 2

Frequency of new case detections of leprosy by grade of physical disability at diagnosis for the overall population and for children under $15 \mathrm{years}$ old in Brazil from 2006 to 2017.

2a) Overall population

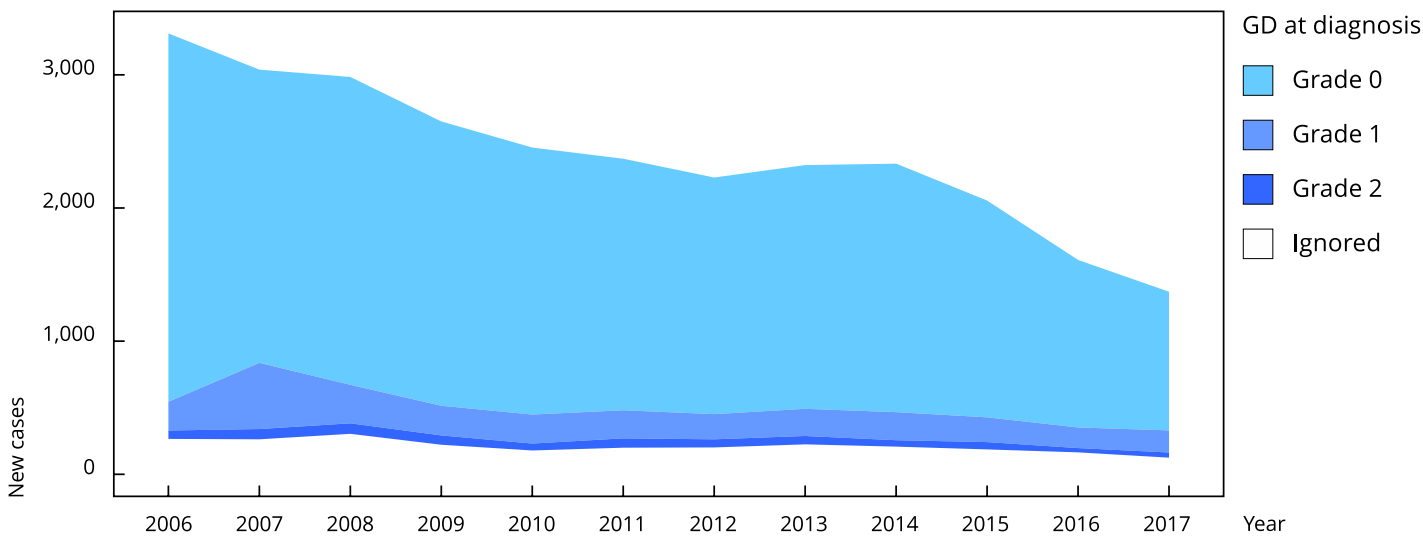

2b) Children under 15 years

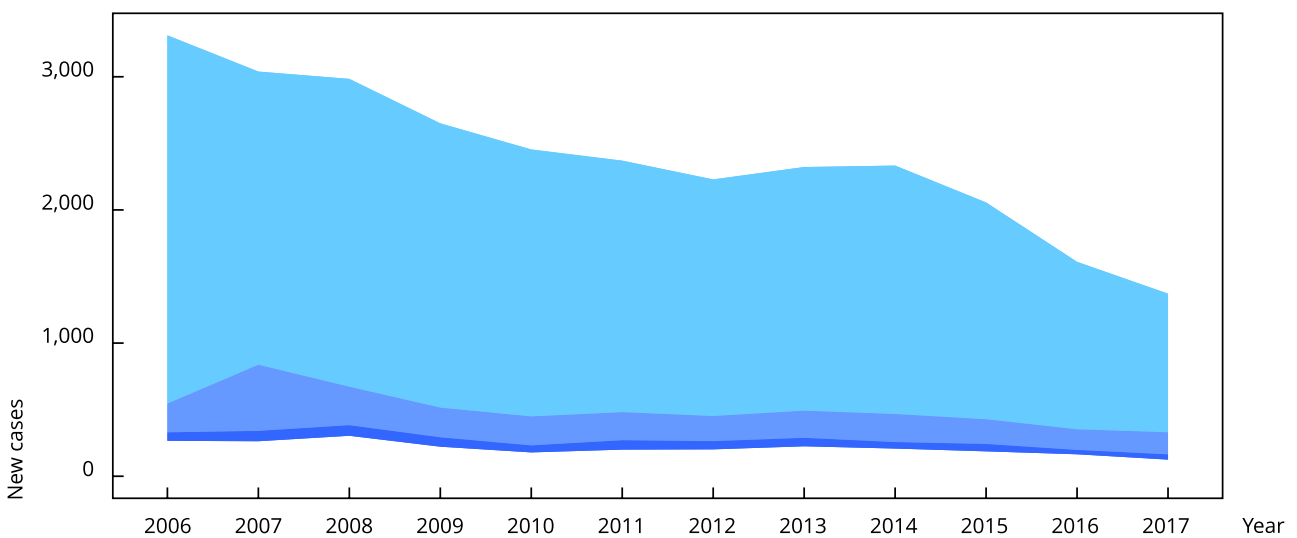

provision of multidrug-therapy, contact surveillance and immunoprophylaxis 5,14,15. An evaluation of the Brazilian Unified National Health System (SUS) achievements in tackling communicable diseases demonstrated that, despite the efforts taken in the last 30 years to control leprosy, they have not been able to fully control the disease transmission, with leprosy NCDR in children as a salient indicator of persistent circulation of $M$. leprae 15,16 .

The higher NCDR among men and the consistent male:female ratio across all years demonstrates an imbalance in leprosy distribution by sex in Brazil. Differences in morbidity between men and women can be determined by social factors related to lifestyle, habits, culture, and behavior 17,18. In general, men may be more vulnerable to illness and more severe forms, mainly due to their poor healthcare seeking behavior coupled with scarcity of specific services addressing their needs 17 . Although NCDRs remain high among children, the increased leprosy trend observed among older adults 19,20 and the increasing number of multibacillary cases are also consistent with the patterns observed in high-income countries, where leprosy was eliminated in the past century 15,21,22,23. 
Figure 3

Distribution of grades of physical disabilities at the diagnosis and in the end of treatment in Brazil in 2006 and in 2017.

3a) 2006

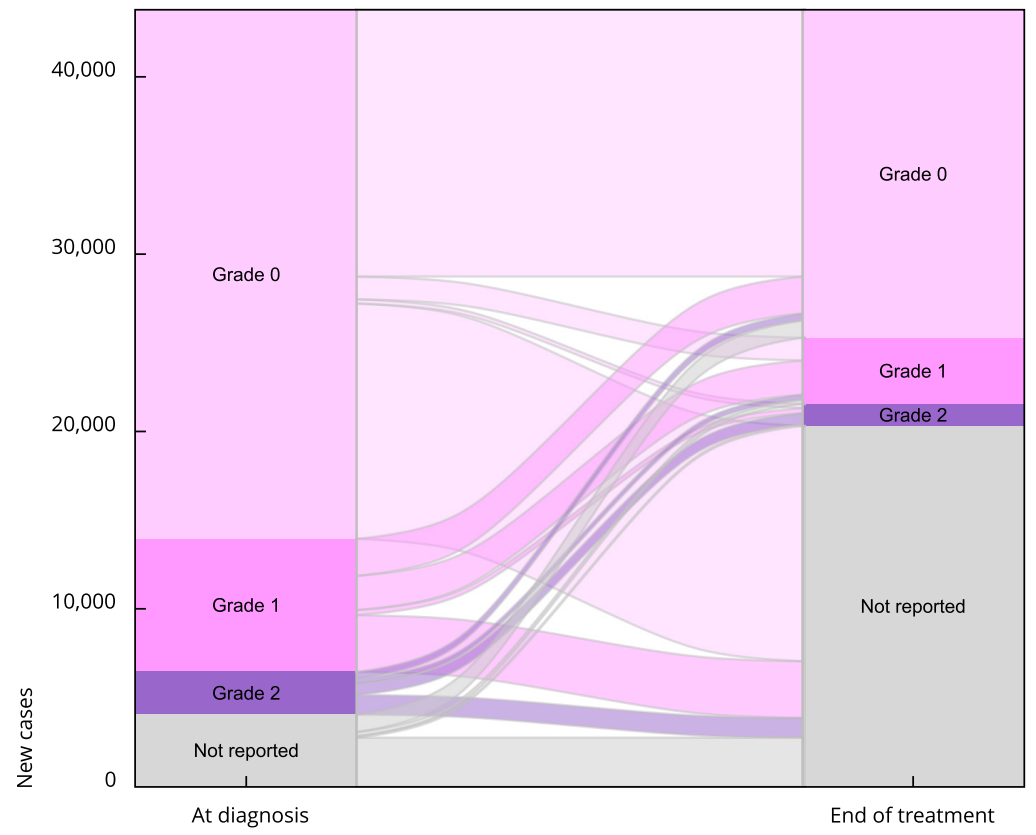

3b) 2017

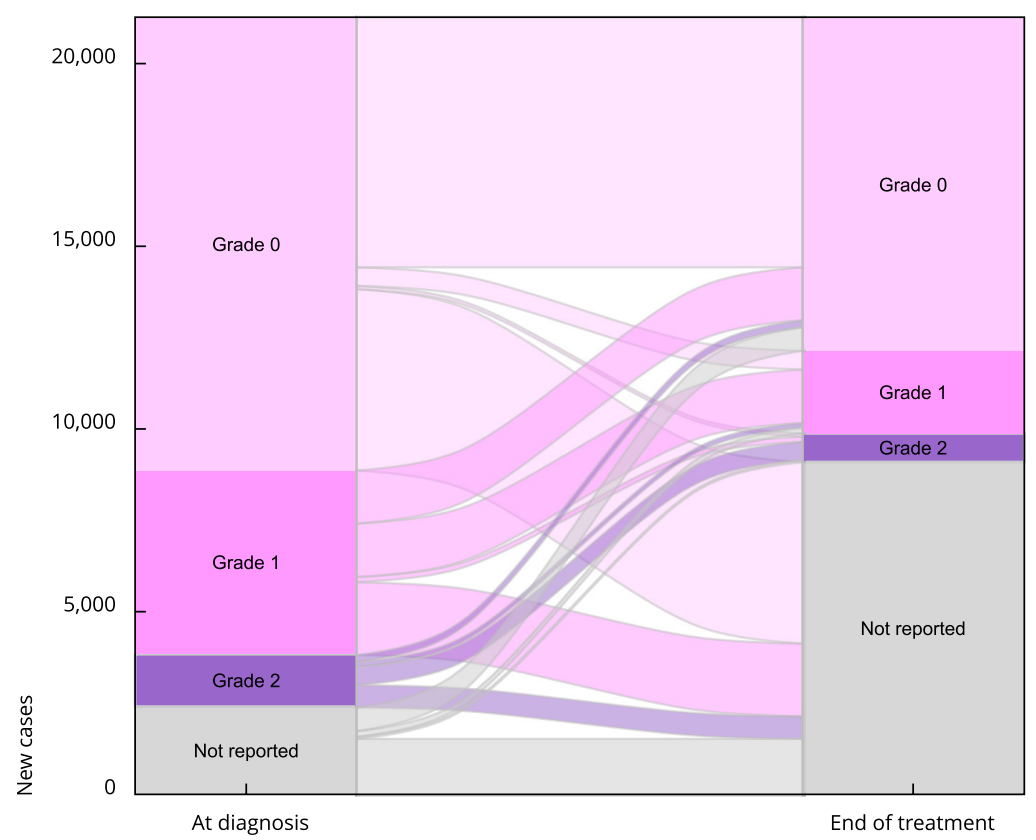


Table 4

Summary table of disability grade at diagnosis versus end of treatment in Brazil from 2006 to 2017 (N = 396,989).

\begin{tabular}{|c|c|c|c|c|c|c|c|c|c|}
\hline \multirow[t]{3}{*}{ At diagnosis } & \multirow[t]{3}{*}{ Total } & \multicolumn{8}{|c|}{ At end of treatment } \\
\hline & & \multicolumn{2}{|c|}{ GOD } & \multicolumn{2}{|c|}{ G1D } & \multicolumn{2}{|c|}{ G2D } & \multicolumn{2}{|c|}{ Grade not reported } \\
\hline & & $\mathbf{n}$ & $\%$ & $\mathbf{n}$ & $\%$ & $\mathbf{n}$ & $\%$ & $\mathbf{n}$ & $\%$ \\
\hline \multicolumn{10}{|l|}{2006} \\
\hline GOD & 29,811 & 15,037 & 50.4 & 1,282 & 4.3 & 235 & 0.8 & 13,257 & 44.5 \\
\hline G1D & 7,495 & 2,087 & 27.8 & 1,929 & 25.7 & 283 & 3.8 & 3,196 & 42.6 \\
\hline G2D & 2,416 & 387 & 16.0 & 282 & 11.7 & 637 & 26.4 & 1,110 & 45.9 \\
\hline Not reported & 4052 & 975 & 24.1 & 235 & 5.8 & 85 & 2.1 & 2,757 & 68.0 \\
\hline \multicolumn{10}{|l|}{2017} \\
\hline GOD & 12,375 & 6,831 & 55.2 & 509 & 4.1 & 86 & 0.7 & 4,949 & 40.0 \\
\hline G1D & 5,032 & 1,447 & 28.8 & 1,459 & 29.0 & 141 & 2.8 & 1,985 & 39.4 \\
\hline G2D & 1,436 & 192 & 13.4 & 129 & 9.0 & 502 & 35.0 & 613 & 42.7 \\
\hline Not reported & 2,401 & 642 & 26.7 & 156 & 6.5 & 55 & 2.3 & 1,548 & 64.5 \\
\hline
\end{tabular}

Note: grade of physical disability (grade 0 - G0D, grade 1 - G1D, and grade 2 - G2D).

Table 5

The distributions of sociodemographic and clinical variables for individuals with grade 2 disabilities (G2D) at diagnosis in Brazil from 2006 to 2017.

\begin{tabular}{|c|c|c|c|c|}
\hline \multirow[t]{2}{*}{ Variables } & \multicolumn{2}{|c|}{$2006(n=4,144)$} & \multicolumn{2}{|c|}{$2017(n=1,436)$} \\
\hline & $\mathbf{n}$ & $\%$ & $\mathbf{n}$ & $\%$ \\
\hline \multicolumn{5}{|l|}{ Sex } \\
\hline Female & 718 & 29.7 & 437 & 30.4 \\
\hline Male & 1,698 & 70.3 & 999 & 69.6 \\
\hline \multicolumn{5}{|l|}{ Age group (years) } \\
\hline$<15$ & 63 & 2.6 & 39 & 2.7 \\
\hline $15-59$ & 1,571 & 65.0 & 821 & 57.2 \\
\hline $60+$ & 782 & 32.4 & 576 & 40.1 \\
\hline \multicolumn{5}{|l|}{ Race/Ethnicity } \\
\hline White & 867 & 35.9 & 387 & 26.9 \\
\hline Brown/Mixed race & 1,063 & 44.0 & 795 & 55.4 \\
\hline Black & 349 & 14.4 & 197 & 13.7 \\
\hline Asian & 30 & 1.2 & 11 & 0.8 \\
\hline Indigenous & 11 & 0.5 & 6 & 0.4 \\
\hline Not reported & 96 & 4.0 & 40 & 2.8 \\
\hline \multicolumn{5}{|l|}{ Level of education } \\
\hline Primary education or lower & 1,850 & 76.6 & 887 & 61.8 \\
\hline Secondary education or higher & 290 & 12.0 & 301 & 21.0 \\
\hline Not reported & 276 & 11.4 & 248 & 17.3 \\
\hline \multicolumn{5}{|l|}{ Region of residence } \\
\hline North & 387 & 16.0 & 304 & 21.2 \\
\hline Northeast & 842 & 34.9 & 552 & 38.4 \\
\hline Southeast & 731 & 30.3 & 317 & 22.1 \\
\hline South & 169 & 7.0 & 65 & 4.5 \\
\hline Central West & 286 & 11.8 & 197 & 13.7 \\
\hline Not reported & 1 & 0.0 & 1 & 0.1 \\
\hline
\end{tabular}

(continues) 
Table 5 (continued)

\begin{tabular}{|c|c|c|c|c|}
\hline \multirow[t]{2}{*}{ Variables } & \multicolumn{2}{|c|}{$2006(n=4,144)$} & \multicolumn{2}{|c|}{$2017(n=1,436)$} \\
\hline & $\mathbf{n}$ & $\%$ & $\mathbf{n}$ & $\%$ \\
\hline \multicolumn{5}{|l|}{ Residential area } \\
\hline Urban & 1,441 & 59.6 & 1,141 & 79.5 \\
\hline Rural & 339 & 14.0 & 251 & 17.5 \\
\hline Not reported & 636 & 26.3 & 44 & 3.1 \\
\hline \multicolumn{5}{|l|}{ Clinical form } \\
\hline Indeterminate & 55 & 2.3 & 48 & 3.3 \\
\hline Tuberculoid & 256 & 10.6 & 79 & 5.5 \\
\hline Borderline & 1,066 & 44.1 & 783 & 54.5 \\
\hline Lepromatous & 858 & 35.5 & 426 & 29.7 \\
\hline Not evaluated & 181 & 7.5 & 100 & 7.0 \\
\hline \multicolumn{5}{|l|}{ Operational classification } \\
\hline Paucibacillary & 293 & 12.1 & 78 & 5.4 \\
\hline Multibacillary & 2,119 & 87.7 & 1,358 & 94.6 \\
\hline Not evaluated & 4 & 0.2 & 0 & 0.0 \\
\hline \multicolumn{5}{|l|}{ Reaction } \\
\hline No reaction & 780 & 32.3 & 809 & 56.3 \\
\hline Type 1 & 220 & 9.1 & 226 & 15.7 \\
\hline Type 2 & 100 & 4.1 & 66 & 4.6 \\
\hline Types 1 and 2 & 44 & 1.8 & 39 & 2.7 \\
\hline Not evaluated & 1,272 & 52.6 & 296 & 20.6 \\
\hline \multicolumn{5}{|l|}{ Reported treatment outcome } \\
\hline Cure & 1,992 & 82.5 & 1,072 & 74.7 \\
\hline Dropout & 119 & 4.9 & 77 & 5.4 \\
\hline Transferred health unit & 195 & 8.1 & 216 & 15.0 \\
\hline Death & 110 & 4.6 & 71 & 4.9 \\
\hline
\end{tabular}

However, the fact that the disease is more frequent among the individuals self-identified as Black and those with a lower level of education, which may be considered proxy variables for social and economic inequality, our results also reinforce the idea of there being social determinants of leprosy in Brazil and disparities in awareness of the disease and access to health services 24,25. In Brazil, individuals identifying as Black have historically experienced racial discrimination associated with reduced access to education, fewer work and income opportunities, and poorer household living conditions 25,26 - social factors that may increase susceptibility to infectious diseases.

While the increased proportion of multibacillary cases indicates a reduction of leprosy endemicity, the increased proportion of G1D and G2D and still high NCDR among children indicates late diagnosis and inadequately detected and persistent transmission of $M$. leprae 13 .

In 2017, 7.6\% of the leprosy cases in Brazil were diagnosed with G2D at the time of detection, higher than the 5.8\% observed around the world in 2017, and among other endemic countries like India (3.6\%) and Indonesia (0.7\%) 27. A recent population-based study evaluating low-income people in Brazil found a high incidence of leprosy among household contacts of patients with multibacillary leprosy (772.1/100,000 person-year) and with G2D (852.1/100,000 person-year) 28, suggesting that severe forms of leprosy may be associated with an increase of transmission. The increase in proportions of physical disabilities observed over the years suggests that it is still necessary to strengthen contact tracing and active case finding in high-incidence areas to improve timely leprosy detection in the country 1 .

Furthermore, the deficits in evaluation of the presence of leprosy-associated physical disabilities at the end of treatment suggests limitations in healthcare capacity and reinforce the need for reducing health disparities and increasing availability of health services ${ }^{9}$. On the other hand, the large proportion of cases transferred to other health units from 2006 to 2017 might suggest decentralization of 
treatment, which started with the family health program implementation and that became a priority for leprosy after 2006. A previous study that took place in a cluster of leprosy in Brazil (2001-2009) observed that a high percentage of municipalities $(93.6 \%)$ have reported detecting at least one leprosy case outside their municipality, sometimes derived from communities more than 1,000km away 29 . These data suggest gaps in the capacity of the decentralized Brazilian health system to detect and provide comprehensive health care to individuals affected by leprosy 29 .

The concentration of leprosy cases among individuals self-identified as Black, Brown, and Indigenous and living in the poorest regions of Brazil, along with the still high proportion of cases that are detected with disabilities and the high number of cases among children reinforces the fact that leprosy remains a public health problem and that early and universally accessible diagnosis still represents an important priority and challenge for leprosy control in the country. Therefore, achieving the control strategy goals requires universal health coverage, with a focus on children. In addition, the country needs an increase in social and financial support, strategies to fight stigma, and intersectoral activities to reduce social and health inequalities, especially racial disparities 9 . Strategies such as conditional cash transfer programs - as Bolsa Família Program - have been associated with a reduction in leprosy detection rates in adults and children 24,30 , and have recently been associated with higher leprosy treatment adherence and cure by acting on the social determinants of this and other poverty-related diseases 31 . However, leprosy continues to disproportionately affect the more deprived regions and vulnerable populations in Brazil.

The Global Leprosy Strategy (2016-2020) was directed at "Acceleration towards a world without leprosy" and incorporated guidelines establishing three main objectives: (i) zero children diagnosed with leprosy with G2D; (ii) reduction to less than 1 case/million inhabitants of new cases of leprosy with G2D at diagnosis; (iii) and zero countries with legislation that allows for discrimination against leprosy 9. Therefore, our data suggest that Brazil has not yet met leprosy-related disability targets. However, these were broad objectives and difficult to achieve in a five-year plan. WHO has a new Global Leprosy Strategy (2021-2030) 32 - "Towards zero leprosy" -, which is focused on interrupting transmission, achieving zero autochthonous cases, and include a more specific care to persons suffering from physical treatment, socioeconomic rehabilitation and mental health impact of leprosy. These bold targets will need even greater funding and political will to provide healthcare that can improve early detection and treatment across all endemic regions of Brazil and that will reach the most affected and vulnerable subgroups.

The interpretation of the results of this study should be done with caution due to the use of secondary data. These data are likely to still represent a underestimation of true incidence of leprosy in Brazil due to (i) poor data completion and possible inconsistencies in the quality of the information and (ii) under-reporting of cases that possibly occur among the poorest individuals and in poorest areas of Brazil 31. Additionally, trends have to be interpreted carefully as we did not perform a time series analysis.

Despite these limitations, the analysis and interpretation of these findings contribute to the development and evaluation of leprosy surveillance activities in Brazil, suggesting the need to reinforce active case finding and continuous monitoring of leprosy patients after multidrug-therapy (MDT), especially after the increasing primary resistance to MDT in Brazil and elsewhere 33,34.

Our results demonstrate some weaknesses of health services in implementing leprosy control actions, especially those related to diagnosis and timely treatment. In addition, these findings reinforce the need to discuss financing for the control of neglected diseases, such as leprosy, as well as the development of new technologies for their diagnosis and treatment. Finally, we highlight that less attention is given to strategies that aim to improve socioeconomic determinants of leprosy and to reduce inequalities in leprosy diagnosis. Leprosy should be included on the social protection agenda to ensure that affected people become priority beneficiaries in specific programs, such as Bolsa Familia Program or as a priority group of social housing programs, such as Minha Casa Minha Vida [My House, My Life Program]. Social protection strategies focusing on leprosy control are especially important in the context of recent increase in leprosy cases in Brazil in the previous year (Brazilian Health Informatics Department. http://tabnet.datasus.gov.br, accessed on 28/Nov/2019) and could be specifically targeted to improve contact tracing, reduce stigmatizing disabilities and prevent further transmission. 


\section{Conclusions}

This study indicates that there was a decreasing trend of leprosy detection rates in Brazil between 2006 and 2017. However, leprosy remains hyperendemic in some regions, and continues to disproportionately affect male, older and Black, Brown and Indigenous populations. Our results reinforce the urgent need to define and strengthen public health interventions targeting people affected by severe forms of leprosy in order to reduce disabilities and stigma, and decrease transmission. Although advances have been observed in health service coverage and social protection programs in recent years, the results indicate the need for recognition, prevention and control actions in areas at highest risk of transmission. We suggest that prioritizing health education activities, active search and contact tracing, and timely treatment using multidrug-therapy are needed to prevent and treat leprosy-related disabilities.

\section{Contributors}

J. M. Pescarini participated in the study conceptualization, data analysis and interpretation, writing of the original draft, and revision and editing of the final manuscript version. C. S. S. Teixeira participated in data analysis and interpretation, writing of the original draft, and revision and editing of the final manuscript version. N. B. Silva and M. $\mathrm{S}$. Natividade participated in the data analysis and interpretation and revision and editing of the final version of the manuscript. M. N. Sanchez, M. L. F. Penna, and J. S. Nery participated in the data interpretation and revision and editing of the final manuscript version. L. C. Rodrigues, M. L. Barreto, and G. O. Penna participated in the study conceptualization, data interpretation, and revision and editing of the final manuscript version. E. B. Brickley participated in the study conceptualization, data analysis and interpretation, and revision and editing of the final manuscript version. All authors had full access to the final version, shared final responsibility for the decision to submit the paper for publication and declare no conflict of interest.

\section{Additional informations}

ORCID: Júlia Moreira Pescarini (0000-0001-87119589); Camila Silveira Silva Teixeira ( 0000-00016340-7957); Nívea Bispo da Silva (0000-00024472-6829); Mauro Niskier Sanchez (0000-00020472-1804); Marcio Santos da Natividade (00000002-3986-5656); Laura Cunha Rodrigues (00000001-9008-660X); Maria Lúcia Fernandes Penna (0000-0003-0371-8037); Maurício Lima Barreto (0000-0002-0215-4930); Elizabeth B. Brickley (0000-0003-0280-2288); Gerson Oliveira Penna (0000-0001-8967-536X); Joilda Silva Nery (00000002-1576-6418).

\section{Acknowledgments}

This study was funded by the U.K. Medical Research Council(MRC; MR/N017250/1), CONFAP/ESRC/ MRC/BBSRC/CNPq/FAPDF 2015 - Neglected Tropical Diseases (FAP-DF 193.000.008/2016) to G. O. Penna and the Wellcome Trust (Grant $202912 / B / 16 / Z$ ). The funding sources had no role in the design, data collection, analysis, interpretation, or writing of this article. 


\section{References}

1. Raposo MT, Reis MC, Caminha AVQ, Heukelbach J, Parker LA, Pastor-Valero M, et al. Grade 2 disabilities in leprosy patients from Brazil: need for follow-up after completion of multidrug therapy. PLoS Negl Trop Dis 2018; 12:e0006645.

2. World Health Organization. Global leprosy update, 2017: reducing the disease burden due to leprosy. Wkly Epidemiol Rec 2018; 93:44556.

3. Silva CLM, Fonseca SC, Kawa H, Palmer DOQ. Spatial distribution of leprosy in Brazil: a literature review. Rev Soc Bras Med Trop 2017; 50:439-49.

4. Rodrigues RN, Leano HAM, Bueno IC, Araújo KMFA, Lana FCF. High-risk areas of leprosy in Brazil between 2001-2015. Rev Bras Enferm 2020; 73:e20180583.

5. Schneider PB, Freitas BHBM. Tendência da hanseníase em menores de 15 anos no Brasil, 2001-2016. Cad Saúde Pública 2018; 34:e0101817.

6. Paes-Sousa R, Schramm JMA, Mendes LVP. Fiscal austerity and the health sector: the cost of adjustments. Ciênc Saúde Colet 2019; 24:4375-84.

7. Pescarini JM, Williamson E, Ichihara MY, Fiaccone RL, Forastiere L, Ramond A, et al. Conditional Cash Transfer Program and leprosy incidence: analysis of 12.9 million families from the 100 Million Brazilian Cohort. Am J Epidemiol 2020; 189:1547-58.

8. Ministério da Saúde. Sala de Apoio à Gestão Estratégica. Situação de saúde. Indicadores de morbidade. Hanseníase. http://sage.saude.gov. $\mathrm{br} / \#$ (accessed on 10/Sep/2020).

9. World Health Organization. Global Leprosy Strategy 2016-2020: acceletariong towards a leprosy-free world. Geneva: World Health Organization; 2016.

10. World Health Organization. Global leprosy update, 2018: moving towards a leprosy free world. Wkly Epidemiol Rec 2019; 94:389-412.

11. Secretaria de Vigilância em Saúde, Ministério da Saúde. Diretrizes para vigilância, atenção e eliminação da hanseníase como problema de saúde pública: manual técnico-operacional. Brasília: Ministério da Saúde; 2016.

12. Santos SD, Penna GO, Costa MCN, Natividade MS, Teixeira MG. Leprosy in children and adolescents under 15 years old in an urban centre in Brazil. Mem Inst Oswaldo Cruz 2016; 111:359-64.

13. Vieira MCA, Nery JS, Paixao ES, de Andrade KVF, Penna GO, Teixeira MG. Leprosy in children under 15 years of age in Brazil: a systematic review of the literature. PLoS Negl Trop Dis 2018; 12:e0006788.

14. Assiri A, Yezli S, Tayeb T, Almasri M, Bamgboye AE, Memish ZA. Eradicating leprosy in Saudi Arabia: outcome of a ten-year surveillance (2003-2012). Travel Med Infect Dis 2014; 12:771-7.
15. Lee J, Kim JP, Nishikiori N, Fine PE. The decline of leprosy in the Republic of Korea: patterns and trends 1977-2013. Lepr Rev 2015; 86:316-27.

16. Teixeira MG, Costa MCN, Paixão ES, Carmo EH, Barreto FR, Penna GO. Conquistas do SUS no enfrentamento das doenças transmissíveis. Ciênc Saúde Colet 2018; 23:1819-28.

17. Juvrud J, Rennels JL. "I don't need help": gender differences in how gender stereotypes predict help-seeking. Sex Roles 2017; 76:27-39.

18. Salgado DM, Knowlton AL, Johnson BL. Men's health-risk and protective behaviors: the effects of masculinity and masculine norms. Psychol Men Masc 2019; 20:266-75.

19. Nobre ML, Illarramendi X, Dupnik KM, Hacker MA, Nery JA, Jerônimo SM, et al. Multibacillary leprosy by population groups in Brazil: lessons from an observational study. PLoS Negl Trop Dis 2017; 11:e0005364.

20. Rocha MCN, Nobre ML, Garcia LP. Temporal trend of leprosy among the elderly in Brazil, 2001-2018. Rev Panam Salud Pública 2020; 44:e12.

21. Irgens LM, Skjærven R. Secular trends in age at onset, sex ratio, and type index in leprosy observed during declining incidence rates. Am J Epidemiol 1985; 122:695-705.

22. Meima A, Irgens LM, Oortmarssen GJV, Richardus H. Disappearance of leprosy from Norway: an exploration of critical factors using an epidemiological modelling approach. Int J Epidemiol 2002; 31:991-1000.

23. Lie H. Why is leprosy decreasing in Norway? Trans R Soc Trop Med Hyg 1929; 22:357-66.

24. Andrade KVF, Nery JS, Oliveira Penna G, Penna L, Barreto M, Pereira SM. Effect of Brazil's Conditional Cash Transfer Programme on the new case detection rate of leprosy in children under 15 years old. Lepr Rev 2018; 89:13-24.

25. Nery JS, Ramond A, Pescarini JM, Alves A, Strina A, Ichihara MY, et al. Socioeconomic determinants of leprosy new case detection in the 100 Million Brazilian Cohort: a population-based linkage study. Lancet Glob Health 2019; 7:e1226-36.

26. Lima M, Prates I. Racial inequalities in Brazil: a persistent challenge. In: Arretche M, editor. Paths of inequality in Brazil. São Paulo: Springer; 2019. p. 113-34.

27. Kerr-Pontes LRS, Montenegro ACD, Barreto ML, Werneck GL, Feldmeier H. Inequality and leprosy in Northeast Brazil: an ecological study. Int J Epidemiol 2004; 33:262-9.

28. Teixeira CSS, Pescarini JM, Alves FJO, Nery JS, Sanchez MN, Teles C, et al. Incidence of and factors associated with leprosy among household contacts of patients with leprosy in Brazil. JAMA Dermatol 2020; 156:640-8. 
29. Alencar CHM, Ramos Jr. AN, Sena Neto SA, Murto C, Alencar MJF, Barbosa JC, et al. Diagnóstico da hanseníase fora do município de residência: uma abordagem espacial, 2001 a 2009. Cad Saúde Pública 2012; 28:1685-98.

30. Nery JS, Pereira SM, Rasella D, Penna ML, Aquino R, Rodrigues LC, et al. Effect of the Brazilian conditional cash transfer and primary health care programs on the new case detection rate of leprosy. PLoS Negl Trop Dis 2014; 8:e3357.

31. Smith WC, van Brakel W, Gillis T, Saunderson P, Richardus JH. The missing millions: a threat to the elimination of leprosy. PLoS Negl Trop Dis 2015; 9:e0003658.
32. World Health Organization. Global Leprosy Strategy 2016-2020: towards zero leprosy. Geneva: World Health Organization; 2021.

33. Cambau E, Saunderson P, Matsuoka M, Cole ST, Kai M, Suffys P, et al. Antimicrobial resistance in leprosy: results of the first prospective open survey conducted by a WHO surveillance network for the period 2009-15. Clin Microbiol Infect 2018; 24:1305-10.

34. Rosa PS, D’Espindula HRS, Melo ACL, Fontes ANB, Finardi AJ, Belone AFF, et al. Emergence and transmission of drug/multidrug-resistant Mycobacterium leprae in a former leprosy colony in the Brazilian Amazon. Clin Infect Dis 2019; 70:2054-61. 


\section{Resumo}

O estudo teve com objetivos descrever as tendências na taxa de detecção de casos novos (TDCN) de hanseníase no Brasil em 2006-2017, global e por subgrupos, e analisar a evolução das características clínicas e terapêuticas dos pacientes, com ênfase nos casos diagnosticados com incapacidade física grau 2. Realizamos um estudo descritivo par analisar casos novos de hanseníase registrados no Sistema de Informação de Agravos de Notificação (SINAN), 2006-2017. Calculamos a TDCN de hanseníase por 100.000 habitantes (global e para individuos $<15 e \geq 15$ anos de idade) por sexo, idade, raça/etnicidade, área urbana/rural e macrorregião do Brasil e estimamos as tendências com o teste não paramétrico de Mann-Kendall. Analisamos as distribuições de casos de acordo com características clínicas relevantes ao longo do tempo. No Brasil, houve uma queda marcante na TDCN global, de 23,4/100.000 em 2006 para 10,3/100.000 em 2017; entre crianças < 15 anos, de 6,94 para 3,20/100.000. A queda foi consistente em todas a regiões brasileiras e em todas as categorias de raça/etnicidade. Até 2017, 70,2\% dos casos eram multibacilares, 30,5\% apresentavam incapacidades físicas grau 1 (G1D) ou grau 2 (G2D) ao diagnóstico e 42,8\% não foram avaliados ao encerramento do tratamento ou alta; os casos com $G 2 D$ ao diagnóstico foram detectados majoritariamente nas áreas urbanas (80\%), e 5\% dos casos faleceram durante o tratamento (devido à hanseníase ou por outras causas). Embora a frequência da TDCN da hanseníase tenha diminuído no Brasil entre 2006 e $2017 \mathrm{em}$ todos os grupos avaliados, o número grande de casos com hanseníase multibacilar, incapacidades físicas ou sem avaliação adequada e entre crianças sugere a necessidade de reforçar o diagnóstico e tratamento oportunos para controlar a hanseníase no Brasil.

Hanseníase; Condições Sociais; Doenças Negligenciadas; Epidemiologia; Estudos de Séries Temporais

\section{Resumen}

Se realizó este trabajo con el fin de describir la tendencia general y en subgrupos de la tasa de detección de nuevos casos de lepra (NCDR por sus siglas en inglés) en Brasil, entre 2006-2017, así como para analizar la evolución de las características clínicas y de tratamiento de los pacientes, con énfasis en los casos diagnosticados con un grado 2 de discapacidad física. Realizamos un estudio descriptivo para analizar los nuevos casos de lepra registrados en el Sistema Brasileño de Información de Enfermedades de Notificación (SINAN), 20062017. Calculamos la NCDR de lepra por cada 100.000 habitantes (general e individuos con una edad $<15 y \geq 15$ años) por sexo, edad, raza/etnicidad, áreas urbanas/rurales y regiones brasileñas, y estimamos las tendencias usando el test no paramétrico de Mann-Kendall. Analizamos las distribuciones de casos según las características clínicas relevantes a lo largo del tiempo. En Brasil, hubo una drástica disminución en general de NCDR de los 23,4/100.000 en 2006, a los 10,3/100.000 en 2017; entre niños < 15 años, desde los 6,94 a los 3,20/100.000. El decremento fue consistente en todas las regiones brasileñas y categorías de razal etnicidad. En 2017, un 70,2\% de los casos fueron multibacilares, un 30,5\% tenían grado 1 (G1D) o 2 (G2D) discapacidad física en el diagnóstico y un 42,8\% no fueron evaluados al completar el tratamiento/ser dados de alta; casos con G2D en el diagnóstico fueron en su mayoría detectados en áreas urbanas (80\%) y un 5\% de los casos murieron durante el tratamiento (lepra u otras causas). A pesar de la frecuencia de lepra los NCDR decrecieron en Brasil de 2006 a 2017, a través de todos los grupos de población evaluados, el elevado número de casos con lepra multibacilar, discapacidad física o sin una adecuada evaluación, y entre niños sugiere la necesidad de reforzar a tiempo el diagnóstico y tratamiento para controlar la lepra en Brasil.

Lepra; Condiciones Sociales; Enfermedades Desatendidas; Epidemiología; Estudios de Series Temporales
Submitted on 20/May/2020

Final version resubmitted on $26 / \mathrm{Oct} / 2020$

Approved on 31/Oct/2020 